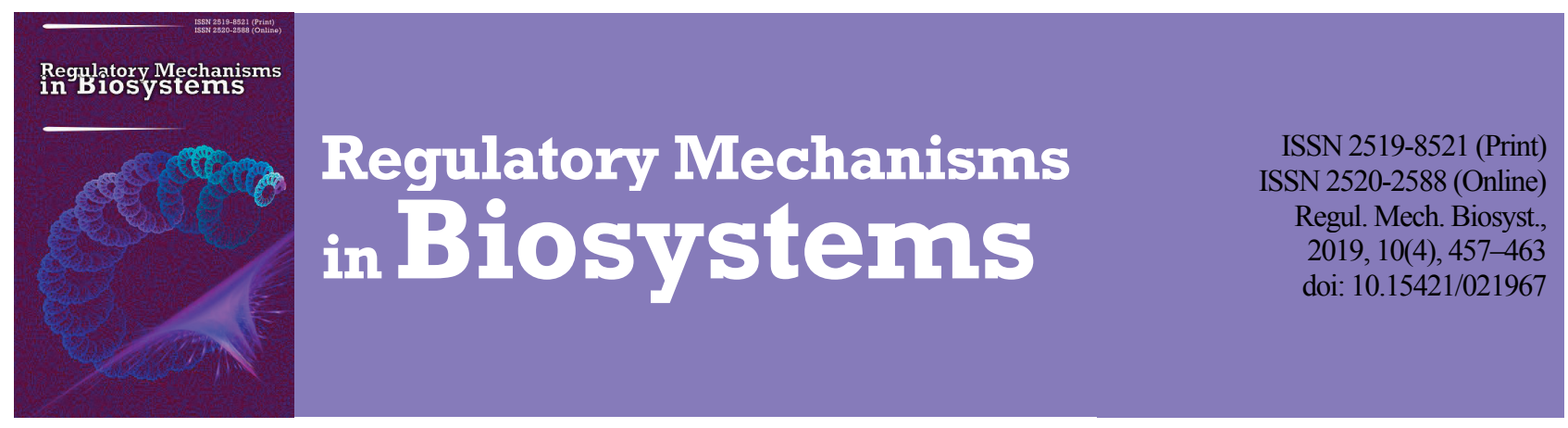

\title{
Dendroindication of ecoclimatic condition in forest remediation area within Northern Steppe of Ukraine
}

\author{
Y. I. Gritsan*, V. M. Lovynska*, S. A. Sytnyk*, A. I. Hetmanchuk** \\ *Dnipro State Agrarian and Economic University, Dnipro, Ukraine \\ **Eastern European National University by Lesya Ukrainka, Lutsk, Ukraine
}

Article info

Received 06.10.2019

Received in revised form

Accepted 03.11.2019

Dnipro State Agrarian and Economic University

S. Yefremov st., 25,

Dnipro, 49060, Ukraine.

Tel.: +38-067-769-63-29

E-mail:glub@ukr.net

Eastern European National

University by Lesya Ukrainka,

Voli Avenue, 13,

Lutsk, 43025, Ukraine.

\section{Introduction}

Forest ecosystems are currently exposed to a wide range of natural and anthropogenic disturbances caused by global warming and climate changes. These disturbances create a real hazard not only to the state of forests and their beneficial functions, but also to human society as a whole (Lindner et al., 2010). In this work, the effect of environmental changes has been identified by the growth response of trees. Vegetation cover in general and woody plants in particular are among the first to respond to negative changes in the air and underground environment. Fire, wind, flooding and drought act as the main abiotic negative factors affecting forest ecosystems. Flooding tolerance was evaluated in terms of tree growth response, level of injury sustained and survival (Kozlowski, 1997) in relation to flooding characteristics and used to express capacity to survive in anoxic conditions (Hook, 1984).

As defined by the same author, mechanisms of "flooding tolerance" include the associated anatomical and physiological adaptations (Kozlowski, 1984; Armstrong et al., 1994; Glenz et al., 2006; Brygadyrenko, 2015, 2016). The process of tree survival under flood conditions primarily depends on their ability to control their metabolism, reach available energy resources, obtain basic gene material, synthesize macromolecules and their ability to protect themselves against post-anoxic injuries. Processes of morphological and physiological adaptations of trees that grow in flood conditions have been studied in numerous works of European scientists (Chirkova \& Gutman, 1972; Hook, 1984; Hughes et al., 1997).

Lack of oxygen caused by flooding is accompanied by accumulation of toxic metabolites and carbon dioxide; it leads to inhibition of new root and branching formations and of existing roots and mycorrhiza development (Ewing, 1996; Kozlowski, 1997). As a result, it leads to a disturbance in the vital processes of the plant body metabolism and photosynthesis inhibition with a proportional decrease in productivity and to a decrease in leaf mass. Tree species are not physiologically adapted to such conditions, and they could die as a result of an excess of the prolonged anoxic environment produced by changes in the channel pattern in response to a flood (Ballesteros-Cánovas et al., 2015).

Location of coal mines near river basins and enclosed water bodies causes their ecological deformation and leads to the death of forest stands because of flooding; as a result, it leads to development of anthropogenic landscapes with unpredictable development prospect, especially typical to the Western part of the Donetsk coal basin, Dnipropetrovsk region (Pakhomov et al., 2008). Tree-ring data provide rare opportunities to understand the ecological dynamics of plant communities (Brienen et al., 2006). Analyses of annual growth rings can be used as source of indirect data to recognize the harmful effects on the environment and can determine the main directions of their improvement (Badeau et al., 1996; Borgaonkar et al., 2009). The results of environmental influence on forest growth have been reflected in several studies, and a lot of them have focused on understanding the relation between radial increment and meteorological factors such as amount of precipitation and air temperature (Cleaveland et al., 2003; Villanueva et al., 2005). Most studies were based on analyses of total ring-width series during the detection of plant growth response to environmental changes. This approach has identified a climatic signal covering a period of several months including the growing season and previous months (Fritts, 1991; Speer, 2010).

In addition, analysis of radial increment in earlywood and latewood parts of total ring-width help to understand seasonal climate variations and their influence on the formation of biomass production (VillanuevaDíaz et al., 2007; Torbenson et al., 2016). Usually earlywood is developed at the beginning of the growing season, whereas latewood is formed at the end of summer or early fall (Fritts, 2001; Vaganov et al., 2006; Griffin et al., 2013; Carlón-Allende et al., 2018). Latewood has higher density and is usually darker than earlywood. Latewood percentage is 
one of the most widely used wood quality characteristics (Larson et al., 2001; Kretschmann et al., 2007). Proportion of latewood has a strong impact on wood specific gravity in conifers (Zobel \& Jett, 1995; Jayawickrama et al., 2011).

Scots pine (Pinus sylvestris L.) is a tree species very common in forests of all Europe and particular within Ukraine, and therefore it has been widely used as timber. Based on cluster analysis and expert knowledge, Glenz et al. (2006) classified 65 Central European tree and shrub species into 5 classes by their flooding tolerance. According to the classification given, Scots pine refers to second lowest class or to floodintolerant trees. The purpose of our research was studying the changes of general ring width, latewood width and earlywood width chronologies in trees of $P$. sylvestris under condition of flooding in the Western Donbass, Dnipropetrovsk region.

\section{Materials and methods}

Study area. The study presented was performed in the steppe zone of Ukraine in Western Donbass, Pavlograd district. Data on amount of precipitation and temperature were obtained from the Pavlogradskaya Meteorological Station as historical data for 32 years. This meteorological station is situated in Dnipropetrovsk region ( $48^{\circ} 05^{\prime}$ N, $35^{\circ} 08^{\prime}$ E, 91 m a.s.l.). Dnipropetrovsk region is an administrative division in the Central part of Ukraine. It located within the middle and lower stream of the Dnieper River.

The subject of the study was Scots pine trees selected from the temporary sample plots laid out in 1961. Sampling was done at two sites, the control (forest reclamation area with no flooding) and the experimental (zone with mining activity in the areas of forest reclamation). Forest reclamation sites were situated on the right valley wall of the Samara River within a mine zone of $5 \mathrm{~km}$ from Pavlograd city in the northeast of Dnipropetrovsk region. The control sampling area has a flat aspect, with altitude of $112 \mathrm{~m}$ a.s.l., northeast aspect and slope $10 \%$. The flood sampling area has also a flat aspect, with altitude of $70 \mathrm{~m}$ a.s.l., northeast aspect and slope $0 \%$.

Climatic date and definition of climate-growth relationships. The climate of the region studied is moderately continental, with mild winters having a small amount of snow and frequent thaws (average January temperature $-5^{\circ} \mathrm{C}$ ) and hot, dry summers with frequent rainstorms and strong southern winds (average July temperature $+22^{\circ} \mathrm{C}$ ). The average annual air temperature is $8.1^{\circ} \mathrm{C}$, the temperature of the soil surface is $10^{\circ} \mathrm{C}$. Duration of the period with temperatures above $+10^{\circ} \mathrm{C}$ is 178 days, and the frost-free period is 187-228 days. Most precipitation falls in the warm period, and the annual quantity of precipitation averages $446 \mathrm{~mm}$. Depth of snow cover reaches $10-15 \mathrm{~cm}$. The period with a stable snow cover continues 3 months and lasts from about December 27 to March 4 . Among the negative climatic phenomena there are thaws, windy frosts, dry winds and dust storms.

Monthly averaged temperatures $\left({ }^{\circ} \mathrm{C}\right)$ and monthly sums of precipitation $(\mathrm{mm})$ were used as explanatory variables. The data were used for making a regional series of annual total precipitation and annual temperatures for the period from 1961 to 1991. Mean annual precipitation for the reference period is $506.0 \mathrm{~mm}$ and annual temperature averages 8.5 , 6.7 and $10.3{ }^{\circ} \mathrm{C}$ for mean, minimum and maximum temperature respectively. The number of rainy days averages 161 .

The sum of positive average monthly air temperatures was taken as the characteristic of heat supply, and of negative temperatures as cooling. Water availability in the warm and cold parts of the year at the weather station was calculated in exact accordance with the value of the average monthly air temperatures.

We used the method of residual mass curves, which allows determination of the directions of long-term changes in climate elements. Primary processing of the data involved calculation precipitation per month in the cold (XI-III) and warm (IV-X) parts of the year. In deviation calculation we used the average data on the entire weather sequence for one or another part of the year. Precipitation of the warm part of the year was characterized by a significant difference in the amplitudes of its fluctuations compared with the precipitation fluctuations in the cold part of the year. Longterm data on temperature and rainfall observations within the territory studied were applied in a detailed analysis of the relation between in- crement and climatic factors. The interval of months for which the analysis was conducted covered the period from April of the previous growing season to July of the current one. The "previous" and "current" seasons were used only in relation to the season or year for which the climate-increment comparison was performed in the correlation analysis. According to our observations, xylogenesis of $P$. sylvestris in the Pavlograd area begin in April and May with cambium activation and a start of earlywood formation at about the same time as swelling of buds begins; it continues during latewood formation in June and July, whereas vegetation may occur to end of October. Thus, the full dendroclimatic year of $P$. sylvestris in the study area begins from April of the previous year to October of the current one, and also includes the rest period from November to March.

The relationship between annual variations in P. sylvestris chronologies and monthly climatic-hydrological variables was established using correlation analysis. The time interval covered the period 1961 to 1991 for the calendar, hydrological, dendrological, and vegetative periods from April of the previous year to July of the current year. The hydrological window covered the period from October of the previous season to September of the current season. For these climatic-hydrological variables, their correlation coefficient with increment, standard error was calculated, and they were tested with Student's t test.

To study temperature and humidity effects on tree growth, groups of years were used, which were characterized by the response uniformmity of the stands studied. These years were termedyears of negative and positive anomalies, which respectively were associated with the inhibition or improvement of woody plant increment values.

Field sampling and data collection. Ten living trees from the control sampling area and ten from the flooded sampling area with straight stems were selected as the sample trees. Table 1 presents the properties of the sample trees from the control and flood sampling areas.

Table 1

Biometric characteristics of pine sample trees in normal $(\mathrm{N})$ and flood $(\mathrm{F})$ condition

\begin{tabular}{lccccccccccc}
\hline & \multicolumn{1}{c}{$\begin{array}{c}\text { Height, } \\
\mathrm{m}\end{array}$} & \multicolumn{1}{c}{$\begin{array}{c}\text { Length of } \\
\text { circumference } \\
\text { at trunk base, } \\
\text { cm }\end{array}$} & $\begin{array}{c}\text { Diameter } \\
\text { at trunk } \\
\text { base, cm }\end{array}$ & $\begin{array}{c}\text { Length of } \\
\text { circumfe- } \\
\text { rence at } \\
1.3 \mathrm{~m}, \mathrm{~cm}\end{array}$ & $\begin{array}{c}\text { Diameter } \\
\text { at } 1.3 \mathrm{~m}, \mathrm{~cm}\end{array}$ \\
& \multicolumn{1}{c}{$\mathrm{N}$} & $\mathrm{F}$ & $\mathrm{N}$ & $\mathrm{F}$ & $\mathrm{N}$ & $\mathrm{F}$ & $\mathrm{N}$ & $\mathrm{F}$ & $\mathrm{N}$ & $\mathrm{F}$ \\
\hline 1 & 12 & 12 & 64 & 65 & 20.4 & 20.7 & 54 & 54 & 17.2 & 17.2 \\
2 & 13 & 12 & 68 & 62 & 21.7 & 19.7 & 56 & 53 & 17.8 & 16.9 \\
3 & 13 & 12 & 72 & 67 & 22.9 & 21.3 & 60 & 56 & 19.1 & 17.8 \\
4 & 14 & 11 & 83 & 78 & 26.4 & 24.8 & 66 & 65 & 21.0 & 20.7 \\
5 & 15 & 10 & 104 & 65 & 33.1 & 20.7 & 89 & 56 & 28.3 & 17.8 \\
6 & 15 & 10 & 72 & 79 & 22.9 & 25.2 & 56 & 70 & 17.8 & 22.3 \\
7 & 15 & 13 & 98 & 82 & 31.2 & 26.1 & 81 & 68 & 25.8 & 21.7 \\
8 & 15 & 12 & 87 & 73 & 27.7 & 23.2 & 71 & 55 & 22.6 & 17.5 \\
9 & 15 & 11 & 82 & 63 & 26.1 & 20.0 & 72 & 49 & 22.9 & 15.6 \\
10 & 15 & 11 & 85 & 59 & 27.1 & 18.8 & 67 & 48 & 21.3 & 15.3 \\
Mean & 14.2 & 11.5 & 81.5 & 69.3 & 26.0 & 22.1 & 67.2 & 57.4 & 21.4 & 18.3 \\
\hline
\end{tabular}

Scots pine trees in the normal condition had a diameter at breast height of $21.4 \pm 3.6 \mathrm{~cm}$ (mean \pm standard deviation), height of $14.2 \pm$ $1.1 \mathrm{~m}$. Sample trees in flood condition were comparable, with a diameter at breast height of $18.3 \pm 2.4 \mathrm{~cm}$, height of $11.5 \pm 0.9 \mathrm{~m}$.

Collecting of samples in the stands was carried out by obtaining cross sections of trees, performed at $1.3 \mathrm{~m}$ height. The samples of wood from the trunk were cut out off its peripheral part on the south side. After selecting model trees, we set the places for boring on the trunk, and the number of cores from one tree was determined after extraction of the first core. The bore was set and perpendicularly introduced into the trunk as near to the root collar as possible, so the loss of annual layers was minimal, and the obtained series of measurements maximally approximated to the true age of the model trees.

The sampled trees aged 32 years were bored at a right angle to the slope direction so as to avoid tension wood. Sampling consisted of collecting tree cores with a Pressler increment borer. The samples were taken and or each model selected, two cores were measured. We obtained the average measurements for trees - total height $(\mathrm{H})$ and diameter at breast height with bark (DBH). Samples of cores were taken from the base $1.3 \mathrm{~m}$ 
above the root collar. The longest radius that was obtained at the line of greatest increment was established by measuring the distance from trunk core to periphery. The cuts were made towards the end of the base on both sides of this line at a distance of $1.5-2.0 \mathrm{~cm}$ to the end of trunk. As a result of this the sample took a trihedral shape, with the help of which detection of false rings and clarification of the boundaries of seasonal parts within annual layer became possible. Preparation and core measurements were carried out in tubular racks. The core inserted into the rack was skinned to a clear appearance of the annual layer edges, then preliminary marking was carried out. Immediately after sampling, the cores were placed in individual paper containers to avoid damage and wood deformation during field research and transportation. In order to reach a target moisture content of $12 \%$ prior to testing, all of the specimens were conditioned in a climate chamber at a temperature of $20^{\circ} \mathrm{C}$ and a relative humidity of $65 \%$ until constant weights of specimens were provided.

Further work with the samples was carried out in the laboratory. For measuring, the cross sections were treated with a sharp knife along the directions where the measurement lines were to be, prior to which the layers were divided according to decades (control samples).

Individual chronological series of radial increment were calculated on each model tree by cross dating of the series of data from all its samples and cores. Extreme or minimal increment values (typical years) were used to check the data accuracy.

The earlywood (EW) and latewood (LW) width for each ring was measured along two radial files (upper and lower portions of the image) and averaged. Earlywood and latewood width within the investigated annual rings were defined according to such qualitative aspects as darkening. Earlywood is light-coloured compared with latewood (Larson, 1969). For a clearer appearance of the season part edges, the surface of the sample was wetted with glycerine when measuring the surface. Growth rings are visible because of the difference in texture between the latewood (usually comprised of relatively small and thicker-walled cells) and the earlywood of the subsequent year (with relatively large and thin-walled cells). The EW and LW widths were measured to the nearest $0.01 \mathrm{~mm}$ using MBS- 1 and MBS-9 microscopes in the units of scale of ocular-monometer. The annual ring widths (RW) were calculated from the EW and LW widths.

Measurement errors and quality of dating were verified with the software Statistica (Version 12.6, USA, 2015). All samples are checked for compliance by normal distribution.

\section{Results}

During the period researched, mean annual ring width (RW), as well as mean increment of earlywood (EW) and latewood (LW), was greater in the pine trees growing on the control site, with a corresponding increase of $5 \%, 3 \%$ and $9 \%$ compared to the experimental variant. To assess the impact of flooding on the change in the RW values of Scots pine trees, at first we initially made samples of air temperature and precipitation from the Pavlograd Weather Station for the hydrological year from previous October to September of the following year (X-XII-I-IX months).

Over the period of ecoclimatic observations of the hydrothermal condition dynamics we have identified irregularity in distribution of precipitation, mainly in spring-summer-autumn periods. A lack of moisture is more typical for spring and autumn. Unstable weather associated with increased anticyclonal activity is characteristic of the cold season of the year. In the area surveyed, the wet period begins in late October and ends in March-April; for a second time it is observed in June-July.

Average annual air temperature of $10.1{ }^{\circ} \mathrm{C}$ and amount of precipitation of $676 \mathrm{~mm}$ serve as a positive extreme, which caused the maximum effect in the formation of Scots pine increment. Whereas, the lowest effect on the process of wood increment was recorded with an average annual temperature of $7.3^{\circ} \mathrm{C}$ with amount of precipitation of $434 \mathrm{~mm}$.

We adopted data on each dendrological year from the second half of the previous vegetation season to the first half of the current one, which to assess the influence of climatic factors on the annual radial growth of Scots pine is a time period characterizing all the features of the growth performance in the studied region. Precipitation of the cold part of the year (November-March) was very effective for preliminary prediction of increment. Regardless of stand location, in the spring-summer period (Aprit-
June) the improvement in increment was usually associated with rainfall in May and June. Meteorological conditions in the period from July to September determine the increment values of the subsequent growing season. Of great practical importance is the question of whether a change in meteorological conditions in only one of these periods can lead to occurrence of increment anomalies. In this regard, we analyzed the dependence of increment on meteorological conditions in years between the peaks of highs and lows within the ascending and descending sections of the curve characterizing the long-term course of changes in the increment of pine stands. Meteorological elements were summarized by groups of years, followed by correlation analysis (Table 2).

\section{Table 2}

Relationship between total precipitation, temperature and radial increment of Scots pine for different meteorological periods

\begin{tabular}{|c|c|c|c|c|c|c|c|}
\hline \multirow{2}{*}{ Months } & \multirow{2}{*}{$\begin{array}{c}\text { Period } \\
\text { and name } \\
\text { of year }\end{array}$} & \multicolumn{2}{|c|}{$\begin{array}{l}\text { Correlation } \\
\text { coefficient }\end{array}$} & \multicolumn{2}{|c|}{ Standard error } & \multicolumn{2}{|c|}{ t-value } \\
\hline & & $\begin{array}{l}\text { precipi- } \\
\text { tation }\end{array}$ & $\begin{array}{l}\text { tempe- } \\
\text { rature }\end{array}$ & $\begin{array}{l}\text { precipi- } \\
\text { tation }\end{array}$ & $\begin{array}{l}\text { tempe- } \\
\text { rature }\end{array}$ & $\begin{array}{l}\text { precipi- } \\
\text { tation }\end{array}$ & $\begin{array}{l}\text { tempe- } \\
\text { rature }\end{array}$ \\
\hline $\begin{array}{l}\text { January- } \\
\text { December }\end{array}$ & $\begin{array}{l}\mathrm{t}-3, \\
\text { calendar }\end{array}$ & 0.471 & 0.410 & 0.311 & 0.322 & 3.59 & 2.89 \\
\hline $\begin{array}{l}\text { January- } \\
\text { December }\end{array}$ & $\begin{array}{l}\mathrm{t}-2 \text {, } \\
\text { calendar }\end{array}$ & 0.573 & 0.444 & 0.289 & 0.316 & 5.02 & 3.19 \\
\hline $\begin{array}{l}\text { January- } \\
\text { December }\end{array}$ & $\begin{array}{l}\mathrm{t}-1 \text {, } \\
\text { calendar }\end{array}$ & $0.752 * *$ & 0.320 & 0.224 & 0.332 & 10.23 & 2.10 \\
\hline $\begin{array}{l}\text { January- } \\
\text { December }\end{array}$ & $\begin{array}{l}\mathrm{t}, \\
\text { calendar }\end{array}$ & 0.610 & 0.360 & 0.279 & 0.316 & 5.76 & 2.43 \\
\hline July-June & $\begin{array}{l}\text { Previous- } \\
\text { currently, } \\
\text { dendrological } \\
\text { Previous- }\end{array}$ & $0.782 * *$ & 0.431 & 0.221 & 0.319 & 11.91 & 3.11 \\
\hline August-July & $\begin{array}{l}\text { currently, } \\
\text { dendrological }\end{array}$ & $0.771^{*}$ & 0.350 & 0.226 & 0.332 & 11.17 & 2.39 \\
\hline $\begin{array}{l}\text { October- } \\
\text { September }\end{array}$ & $\begin{array}{l}\text { Previous- } \\
\text { currently, } \\
\text { hydrological }\end{array}$ & $0.702^{*}$ & 0.341 & 0.251 & 0.331 & 8.21 & 2.25 \\
\hline $\begin{array}{l}\text { November- } \\
\text { March }\end{array}$ & $\begin{array}{l}\text { Previous- } \\
\text { currently, } \\
\text { cooling period }\end{array}$ & 0.552 & 0.530 & 0.295 & 0.298 & 4.67 & 4.35 \\
\hline $\begin{array}{l}\text { April- } \\
\text { October }\end{array}$ & $\begin{array}{l}\text { Currently, } \\
\text { warm period }\end{array}$ & $0.730^{*}$ & 0.581 & 0.241 & 0.342 & 5.16 & 9.17 \\
\hline $\begin{array}{l}\text { August- } \\
\text { September }\end{array}$ & $\begin{array}{l}\text { Previous, ge- } \\
\text { nerative period }\end{array}$ & $0.729^{*}$ & $0.660^{*}$ & 0.241 & 0.266 & 9.17 & 6.82 \\
\hline $\begin{array}{l}\text { October- } \\
\text { March }\end{array}$ & $\begin{array}{l}\text { Previous- } \\
\text { currently, } \\
\text { accumulation } \\
\text { period }\end{array}$ & 0.601 & 0.560 & 0.282 & 0.292 & 5.61 & 4.80 \\
\hline April-July & $\begin{array}{l}\text { Currently, } \\
\text { growing season }\end{array}$ & $0.692 *$ & $0.673^{*}$ & 0.255 & 0.261 & 7.12 & 7.69 \\
\hline
\end{tabular}

Note: $\mathrm{t}-3$ - before three years to increment, $\mathrm{t}-2$ - before two years to increment, $\mathrm{t}-1$ - before one year to increment, $\mathrm{t}-$ current year; Asterisks indicate statistically significant period: $*_{-} \mathrm{P}<0.05,{ }^{*}-\mathrm{P}<0.01$.

The data processing allows us to represent the importance and role of meteorological elements in the following periods: reproductive development (process of specialized plant organs' formation); cumulative state (summation of environmental factors influencing growth development); assimilation development (process of assimilation apparatus and annual ring formation) of pine stands. In the area of survey, the optimum air temperature is on average $17.0^{\circ} \mathrm{C}$ during the assimilation period when a maximum increment of annual ring occurs. Average temperature of $18.9^{\circ} \mathrm{C}$ is favourable in the reproductive period. In the years with a maximum increment of annual ring, humidification values increase 1.4-1.5 times more than in years with a minimum increment. So, the mean optimal amount of precipitation in the generative period is $138.3 \mathrm{~mm}$, in the cumulative period is 186.5 , and in the assimilation period is $131.1 \mathrm{~mm}$. Having regard to the clear response of forest stands to May rainfall, we consider their average effective value as $71.4 \mathrm{~mm}$.

Figure 1 shows dendroclimatogram that demonstrates the distribution of temperature and precipitation by months with highest and lowest increment of Scots pine in normal environmental conditions. It is obvious that the greatest differences in the years of maximum and minimum recorded radial increment were observed in amount of precipitation from February 
to June with its significant decrease in July and August. At the same time, slight differences in the average monthly air temperature were registered from June to September, ranging from 21 to $25^{\circ} \mathrm{C}$. A very different situation was in the cold season in December, January and February. During the negative anomalies of Scots pine increment a deeper cooling of the territory occurred with less precipitation in January and February, where the average February temperatures vary by almost $7{ }^{\circ} \mathrm{C}$. Preliminary results on assessment of influence of climatic factors on formation of increment served as the basis for comparing the radial pine increment after adding flooding as an additional impact factor in the research system.

The analysis of the data obtained allowed us to trace the weather changes and long-term increment trends in the control and flood areas using living specimens of Scots pine (Fig. 2, 3). There is no doubt that there was a high-degree of consistency between two curves characterizing the same reaction in the trees at the control and in the flooding area of mine workings. However, the response amplitudes were significantly different.

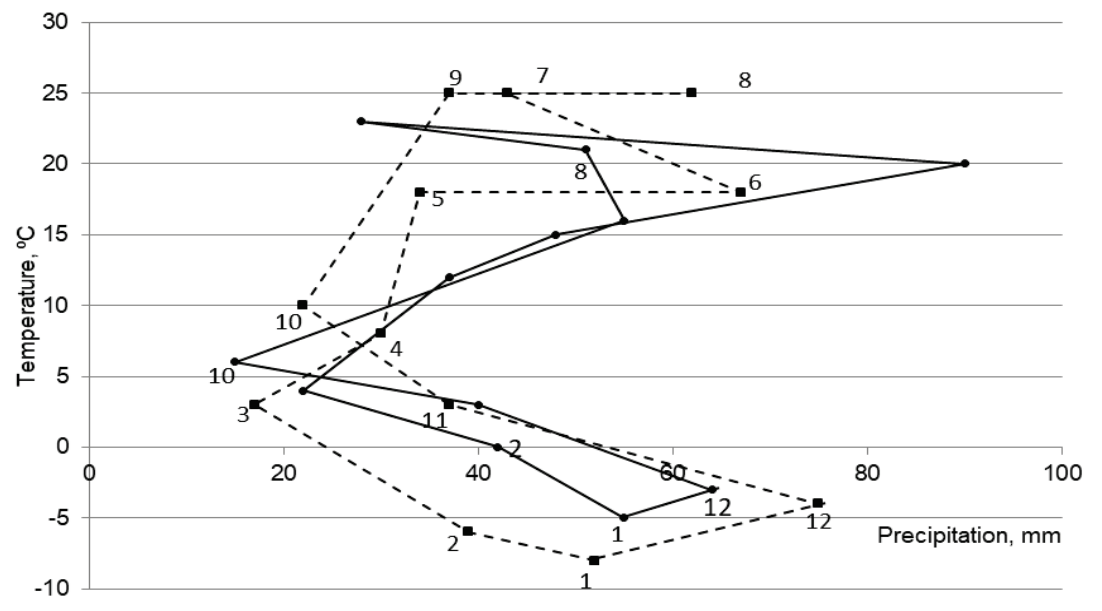

Fig. 1. Dendroclimatogram temperature-precipitation in years of maximum (solid line)

and minimum (dotted line) Scots pine increment; 10-12-1-9-months of hydrological year

It should be noted that maximum increment values were registered for both RW and EW at average annual temperature of about $9{ }^{\circ} \mathrm{C}$, and the maximum on the plants of the flood area. In general, we did not establish a certain influence pattern of average annual temperature on the values of whole ring and early wood increment. Curves constructed for these components have an abrupt pattern, although in most cases the values of the absolute increment are higher in the control variant. A much lesser variation of changes was noted for $\mathrm{LW}$, both of control and experimental groups. In flood conditions, pine trees are situated in the zone with greater deficit of soil moisture since their planting, which determined their longterm clear response to fluctuation of precipitation. Years with the sum of precipitation amounting to $368,434,447$ and $581 \mathrm{~mm}$ were the most unfavourable for trunk radial increment. As can be seen from the presented data, the indicated years were characterized by low values, and the additional deterioration of soil water supply in the area of mine workings leads to a weak formation of increment.

Figure 3 shows the influence of precipitation on Scots pine radial increment changes. Similar to the temperature regime, hydrological conditions do not give a clearly expressed growth response of plants regardless of the habitat characteristics of the plants studied. The maximum effect of
RW and EW formation was observed in plants of the experimental group, besides with a low precipitation amount $368 \mathrm{~mm}$. For the same group of plants, a peak of high RW and EW values was also observed in the year with precipitation amount of $676 \mathrm{~mm}$. Along with the maximum effect, conditions of flooding caused also an absolutely opposite response in plants with the formation of a minimum RW and EW with amount of precipitation $437 \mathrm{~mm}$ per year. Relative to the control group, it should be noted that RW and EW values, like the flooding variant, have a jump-like pattern of changes, while not depending directly on the amount of precipitation during the year. However, the curves showing dependence of the increment on hydrological conditions have less variability of changes in comparison with the group under flood conditions. On the contrary, radial increment values of LW in two groups of plants studied in the annual dynamics have insignificant magnitude of $\mathrm{EW}$ fluctuations compared with $\mathrm{RW}$, with a less significant share of precipitation influence, respectively. LW values ranged $0.2-2.3 \mathrm{~mm}$ and were slightly higher in the control plant group compared to plants of the experimental group.

In general, the data obtained on the average values of the RW were higher by $17 \%$ for the group of control plants, compared with trees growing in the flood area, by $30.5 \%$ for LW and $11.5 \%$ for EW (Table 3 ).

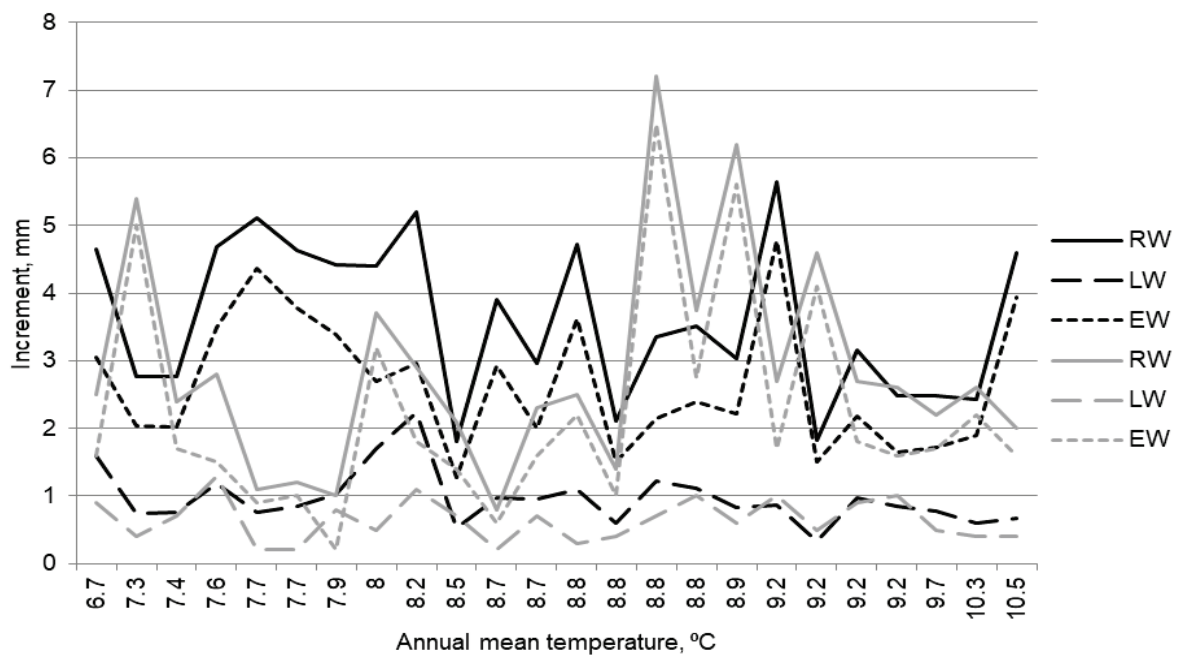

Fig. 2. Dependence of change of Scots pine increment in normal (black line) and flood (grey line) conditions on annual mean temperature: variables are as follows: RW - ring width, LW - latewood width, EW - earlywood width 


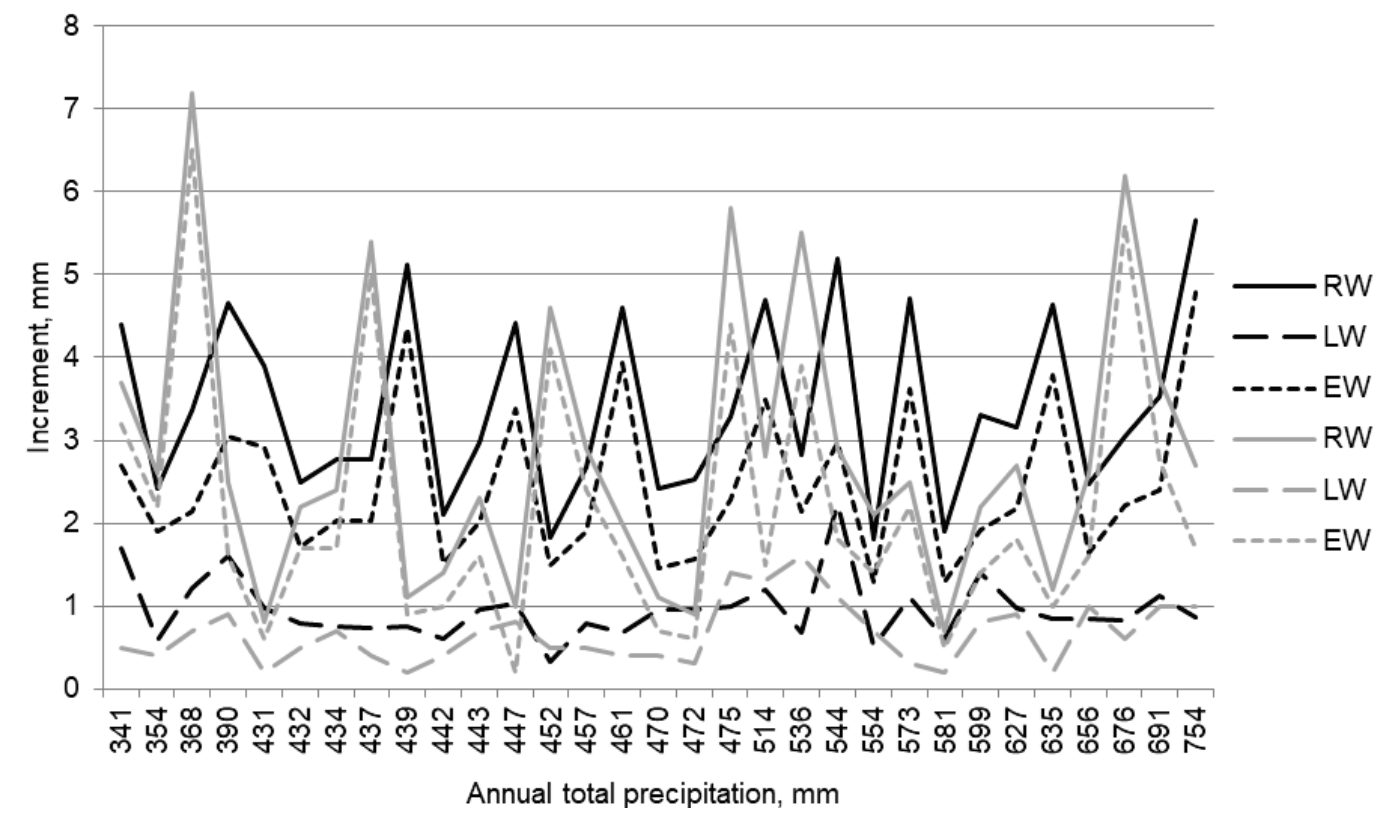

Fig. 3. Dependence of change of Scots pine increment in normal (black line) and flood (grey line) conditions on annual total precipitation: variables are as follows: RW - ring width, LW - latewood width, EW - earlywood width

Calculation of the pair correlation coefficients showed the existence of a statistical relationship of weak contingency between width of annual trunk rings and individual factorial characteristics (Table 4). Thus, for example, the relationship between pine radial increment and air temperature in the conditions of flooding was characterized by not significant correlation coefficients in a range 0.22-0.31.

In contrast, width of the annual ring had an inverse correlation with the temperature, but not more than -0.28 under normal conditions.

Table 3

Main distributional statistics of increment of Scots pine in the normal and flood condition

\begin{tabular}{ccccccc}
\hline Index & Mean+SE & Minimal value & Maximal value & SD & Skewness & Kurtosis \\
\hline NW & $3.41 \pm 0.20$ & 1.80 & 5.65 & 1.11 & 0.39 & -1.05 \\
LW & $0.95 \pm 0.07$ & 0.33 & 2.23 & 0.38 & 1.53 & 3.42 \\
EW & $2.45 \pm 0.17$ & 1.28 & 4.78 & 0.94 & 0.88 & -0.08 \\
\hline \multicolumn{7}{c}{ Flood condition } \\
\hline RW & $2.83 \pm 0.31$ & 0.70 & 7.20 & 1.70 & 1.01 & 0.40 \\
LW & $0.66 \pm 0.06$ & 0.20 & 1.60 & 0.37 & 0.77 & 0.07 \\
EW & $2.17 \pm 0.28$ & 0.20 & 6.50 & 1.57 & 1.29 & 1.08 \\
\hline
\end{tabular}

Note: $\mathrm{SE}$ - standard error, $\mathrm{SD}$ - standard deviation.

\section{Table 4}

Correlation coefficients of pine increment

with factorial characteristics in different habitat conditions

\begin{tabular}{llrrr}
\hline \multirow{2}{*}{ Climate factor } & \multirow{2}{*}{ Condition } & \multicolumn{3}{c}{ Index } \\
\cline { 3 - 5 } & & RW & LW & EW \\
\hline \multirow{2}{*}{ Temperature } & norm & -0.11 & -0.28 & -0.01 \\
& flood & 0.31 & 0.22 & 0.28 \\
\multirow{2}{*}{ Precipitation } & norm & 0.14 & -0.04 & 0.18 \\
& flood & -0.01 & 0.28 & -0.07 \\
\hline
\end{tabular}

A positive not significant correlation $(r=0.271)$ between the increment values of early and late wood was recorded for Scots pine plants growing on the control variant. Close value of pair correlation $(r=0.267)$ between those values was also noted for plants of the experimental group.

\section{Discussion}

The obtained results make it possible to underscore the importance of the winter temperature regime once again for coniferous trees, which has a significant impact on the formation of radial increment in the next growing season. Dendroclimatological research using Scots pine tree- ring widths has been conducted, e.g. by Cedro (2001), Vitas (2004), Zunde et al. (2008), Lindholm et al. (2010).

The results of observations showed that the growth of the pine trunk along the radius in the investigated conditions usually starts in the first and second decades of May, which was due to conditions of air temperature. Radial increment, investigated in this study, was finished in the first or second decade of August, when the average monthly temperature was $21^{\circ} \mathrm{C}$, and the amount of precipitation was $51 \mathrm{~mm}$. According to studies of several authors, the start of trunk radial increment usually coincides with the start of needles' growth, and it is finished in I-II decades of August (Vaganov \& Kachaev, 1992; Zabuga \& Zabuga, 2003; Nikolaeva \& Savchuk, 2008). Development (differentiation, growth by stretching, maturation) of early tracheids covers the period from the III decade of May to the beginning of August, and late tracheids from the beginning of June and almost to the end of September (Antonova, 1999). According to assumption of García-Suárez (2009), more favourable climatic conditions lead to a longer growing season for pines, followed by a weakening of the summer temperature influence. Studies on relationship between climatic factors in winter and tree growth have shown that it is either negative or absent (Krasnobaeva \& Mityashkina, 2006; Nikolaeva \& Savchuk, 2008).

Conditions of habitat definitely brought about the observed differences in the trend of changes in Scots pine increment values depending on the average annual air temperature. According to Zabuga \& Zabuga (2003), the magnitude of radial increment variation and the proportion of external factors influencing them may reflect the strategy of plant growth processes and specificity of lateral meristem response of pine trees. In this case, a relatively high proportion of the increment direct response to the impact of environmental factors was determined by the provision of apical growth with products of photosynthesis, primarily reserves of assimilates created during the previous autumn and used for shoot growing in the current year. In optimal soil moisture conditions, those favourable for photosynthesis are engendered which guarantee sufficient tissue hydration and a high level of transpiration (Scherbatyuk et al., 1990; Suvorova et al., 2005). In such years the greatest radial increment in coniferous xylem is formed (Vaganov \& Kachaev, 1992). The photosynthesis intensity is inhibited under the influence of constant soil flood, which leads to a decrease in formation of ring width. This process has been recorded in our studies and is consistent with the results obtained by Arbellay et al. (2012a, 2012b) and Ballesteros-Canovas et al. (2010a), who note that in coniferous trees, the main indicators are decreased ring widths along with a significant reduction in earlywood tracheid size.

The contribution of latewood to the total annual increment is $27.9 \%$ in the case of its formation in the group of plants of the control variant, 
whereas in case of flooding it is less and amounted $23.3 \%$. This is inconsistent with data obtained for deciduous plant species by a number of authors, who note a greater contribution of latewood width to ring width, compared with earlywood width (Phipps 1982; Tardif 1996; Lebourgeois et al., 2004).

As in our work, a similar inverse correlation with the temperature regime and a direct correlation with the amount of precipitation per year were established by Zabuga \& Zabuga (2006) for plants growing in normal conditions of the forest-steppe Prebaikalia, Russia. Researchers who studied coniferous plant species in the dryland communities of southern Russia (Nikolaeva et al., 2006) also noted a positive correlation between the general ring width and precipitation of the growing season (or individual months of vegetation). At the same time, as shown in our results, correlation with temperature was negative (Glebov \& Litvinenko, 1976). On the other hand, Ferrio et al. (2015) investigated two pines, of which one was $P$. sylvestris $\mathrm{L}$. and found that spring precipitation showed a strong negative effect on earlywood, while temperature was positively correlated. Such effect the authors related to the suggestion that the spring effect is mainly related to enrichment effects at the leaf level, which in turn are associated with the tight stomatal regulation of pines (Ballesteros et al., 2010). Similar to the data obtained, a positive correlation between the latewood width in one year and the earlywood width in the following year is recorded in a number of publications (Phipps, 1982; Tardif, 1996; Lebourgeois et al., 2004).

\section{Conclusions}

Analysis carried out on the assessment of Scots pine increment allowed us to reveal the characteristics of fluctuations caused by annual temperature and sum of precipitation. The greatest differences in the years of highest and lowest increment values of Scots pine were observed in the amount of precipitation falling from February to June. Increment values of pine under flood conditions were characterized by large amplitude of fluctuations in values of WR and EW compared with fluctuations in LW values compared with the trees growing under normal conditions. Average WR, EW, LW values of plants growing under normal conditions were higher by $17.0 \%, 30.5 \%, 11.5 \%$, compared with the trees growing in the flood area. Degree of closeness of the pair correlation between the studied increment parameters and temperature was higher compared to the average annual precipitation. Variability of the annual ring width in conditions of flooding had a direct correlation with variability of the average ring width for the period of its temperature growth and the negative correlation in normal conditions of plant growth.

\section{References}

Antonova, G. F., Perevoznikova, V. D., \& Stasava, V. V. (1999). Vliyanie uslovij proizrastaniya na strukturu godichnogo sloya drevesiny i produktivnost' sosny obyknovennoj [The influence of growing conditions on the structure of the annual wood layer and the productivity of Scots pine]. Forestry, 6, 45-53 (in Russian).

Arbellay, E., Corona, C., Stoffel, M., Fonti, P., \& Decaulne, A. (2012a). Defining an adequate sample of earlywood vessels for retrospective injury detection in diffuse-porous species. PLoS One 7, e38824.

Arbellay, E., Fonti, P., \& Stoffel, M. (2012b). Duration and extension of anatomical changes in wood structure after cambial injury. Journal of Experimental Botany, 63, 3271-3277.

Armstrong, W., Brandle, R., \& Jackson, M. B. (1994). Mechanisms of flood tolerance in plants. Acta Botanica Neerlandica, 43, 307-358.

Badeau, V., Becker, M., Bert, D., Dupouey, J. L., Lebourgeois, F., \& Picard, J. F. (1996). Long-term growth trends of trees: Ten years of dendrochronological studies in France. In: Spiecker, H., Mielikainen, K., Kohl, M., \& Skovsgaard, J. P. (Eds.). Growth trends in European forests. Springer-Verlag, Berlin, Heidelberg, New York. Pp. 167-182.

Ballesteros-Cánovas, J. A., Stoffel, M., St George, S., \& Hirschboeck, K. (2015). A review of flood records from tree rings. Progress in Physical Geography: Earth and Environment, 39(6), 794-816.

Ballesterosi, J. A., Stoffel, M., Bodoque, J. M., Bollschweiler, M., Hitz, O., \& DíezHerrero, A. (2010). Changes in wood anatomy in tree rings of Pinus pinaster A It. following wounding by flash floods. Tree-Ring Research, 66(2), 93-103.

Barredo, J.-I. (2009). Normalised flood losses in Europe: 1970-2006. Natural Hazards and Earth System Science, 9 (1), 97-104.
Borgaonkar, H. P., Somaru, R., \& Sikder, A. B. (2009). Assessment of tree-ring analysis of high-elevation Cedrus deodara D. Don from Western Himalaya (India) in relation to climate and glacier fluctuations. Dendrochronologia, 27, 59-69.

Brienen, R. J. W., \& Zuidema, P. A. (2006). The use of tree rings in tropical forest management: Projecting timber yields of four Bolivian tree species. Forest Ecology and Management, 226, 256-267.

Brygadyrenko, V. V. (2015). Influence of tree crown density and density of the herbaceous layer on the structure of litter macrofauna of deciduous forests of Ukraine's steppe zone. Visnyk of Dnipropetrovsk University, Biology, Ecology, 23(2), 134-148.

Brygadyrenko, V. V. (2016). Influence of litter thickness on the structure of litter macrofauna of deciduous forests of Ukraine's steppe zone. Visnyk of Dnipropetrovsk University, Biology, Ecology, 24(1), 240-248.

Carlón-Allende, T., Villanueva-Díaz, H., Mendoza, M. E., \& Pérez-Salicrup, D. R. (2018). Climatic signal in earlywood and latewood in conifer forests in the Monarch Butterfly biosphere reserve, Mexico. Tree-Ring Research, 74(1), 63-75.

Castagneri, D., Nola, P., Motta, R., \& Carrer, M. (2014). Summer climate variability over the last 250 years differently affected tree species radial growth in a mesic Fagus-Abies-Picea old-growth forest. Forest Ecology and Management, 320, 21-29.

Cedro, A. (2001). Dependence of radial growth of Pinus sylvestris L. from Western Pomerania on the rainfall and temperature conditions. Geochronometria, $20,69-74$

Chirkova, T. V., \& Gutman, T. S. (1972). Physiological role of branch lenticels in willow and poplar under conditions of root anaerobiosis. Soviet Plant Physiology, 19, 289-295.

Cleaveland, M. K., Stahle, D. W., Therrell, M. D., Villanueva-Diaz, J., \& Burns, B. T. (2003). Tree-ring reconstructed winter precipitation and tropical teleconnections in Durango, Mexico. Climatic Change, 59, 369-388.

Dankers, R. \& Feyen, L. (2008). Climate change impact on flood hazard in Europe: An assessment based on highresolution climate simulations. Journal of Geophysical Research, 113, D19105.

Ewing, K. (1996). Tolerance of four wetland plant species to flooding and sediment deposition. Environmental and Experimental Botany, 36(2), 131-146.

Ferrio, J. P., Díez-Herrero, A., Tarrés, D., Ballesteros-Cánovas, J. A., Aguilera, M., \& Bodoque, J. M. (2015). Using stable isotopes of oxygen from treerings to study the origin of past flood events: first results from the iberian peninsula. Quaternaire, 26(1), 67-80.

Fritts, H. C. (1991). Reconstructing large-scale climatic patterns from tree-ring data: A diagnostic analysis. Tucson \& London, University of Arizona Press.

García-Suárez, A. M., Butler, C. J., \& Baillie, M. G. L. (2009). Climate signal in tree-ring chronologies in a temperate climate: A multi-species approach. Dendrochronologia, 27(3), 183-198.

Glebov, F. Z., \& Litvinenko, V. I. (1976). Dinamika shiriny godichnyh kolec v svyazi s meteorologicheskimi pokazatelyami v razlichnyh tipah bolotnyh lesov [Dynamics of annual rings width due to meteorological indicators in various types of swamp forests]. Forestry, 4, 56-62 (in Russian).

Glenz, C., Schlaepfer, R., Iorgulescu, I., \& Kienast, F. (2006). Flooding tolerance of Central European tree and shrub species. Forest Ecology and Management, 235, 1-13.

Griffin, D. R., Meko, D. M., Touchan, R., Leavitt, S. W., \& Woodhouse, C. A. (2011). Latewood chronology development for summer-moisture reconstruction in the US Southwest. Tree Ring Research, 67, 87-101.

Hook, D. D. (1984). Adaptations to flooding with fresh water. In: Kozlowski, T. T. (Ed.). Flooding and Plant Growth. Academic Press, Orlando. Pp. 265-294.

Hughes, F. M. R., Harris, T., Richards, K., Pautou, G., Hames, A. E., Barsoum, N., Girel, J., Peiry, J.-L., \& Foussadier, R. (1997). Woody riparian species response to different soil moisture conditions: Laboratory experiments on Alnus incana (L.) Moench. Global Ecology and Biogeography Letters, 6, 247-256.

Jayawickrama, K., Mckeand, S., Jett, J. B., \& Wheeler, E. (1997). Date of earlywood-latewood transition in provenances and families of loblolly pine, and its relationship to growth phenology and juvenile wood specific gravity. Canadian Journal of Forest Research, 27, 1245-1253.

Kozlowski, T. T. (1997). Responses of woody plants to flooding and salinity. Tree Physiology, 17(7), 490.

Krasnobaeva, K. V., \& Mityashkina, S. Y. (2006). Dendroclimatic analysis of the growth of Scots pine in geographical cultures. Forestry, 4, 45-51.

Larson, P. R. (1969). Wood formation and the concept of wood quality. Yale University, School of Forestry.

Lebourgeois, F., Cousseau, G., \& Ducos, Y. (2004). Climate - treegrowth relationships of Quercus petraea Mill. stand in the Forest of Bercé ("Futaie des Clos", Sarthe, France). Annals of Forest Science, 61, 361-372.

Lindholm, M., Lehtonen, H., Kolstrom, T., Merilainen, J., Eronen, M., \& Timonen, M. (2000). Climatic signals extracted from ring-width chronologies of Scots pines from the northern, middle and southern parts of boreal forest belt in Finland. Silva Fennica, 34, 317-330.

Lindner, M., Maroschek, M., Netherer, S., Kremer, A., Barbati, A., Garcia-Gonzalo, J., Seidl, R., Delzon, S., Corona, P., Kolström, M., Lexer, M. J., \& Marchetti, M. 
(2010). Climate change impacts, adaptive capacity, and vulnerability of European forest ecosystems. Forest Ecology and Management, 259, 698-709.

Nikolaeva, S. A., Savchuk, D. A., \& Bocharov, A. Y. (2006). Vliyanie vneshnih i vnutrennih faktorov na produktivnost' derev'ev [Effect of extemal and internal factors on tree productivity]. In: Zuev, V. V. (Ed.). Bioindication of stratospheric ozone. Publishing House of the SD RAS, Novosibirsk. Pp. 118-131 (in Russian).

Nikolaeva, S. A., \& Savchuk, D. A. (2008). Klimatogennaya reakciya derev'ev sosny na yuge Tomskoj oblasti [Climatogenetic response of pine trees in southem Tomsk oblast]. Journal of Siberian Federal University, Biology, 1(4), 400413 (in Russian).

Pakhomov, O., Kulbachko, Y., Didur, O., \& Loza, I. (2008). Mining dump rehabilitation: The potential role of bigeminate-legged millipeds (Diplopoda) and artificial mixed-soil habitats. In: Apostol, I., Barry, D. L., Coldewey, W. G., \& Reimer, D. W. G. (Eds.). Optimisation of disaster forecasting and prevention measures in the context of human and social dynamics. Nato science for peace and security series E-human and societal dynamics. Chisinau, Moldova, 52, 163-171.

Phipps, R. L. (1982). Comments on the interpretation of climatic information from tree-rings, eastern North America. Tree-Ring Bulletin, 42, 11-22.

Scherbatyuk, A. S., Yankova, L. S., \& Rusakova, L. V. (1990). Ekologo-fiziologicheskie osobennosti gazoobmena hvojnyh [Ecological and physiological characteristics of coniferous gas exchange]. Forestry, 4, 3-10 (in Russian).

Speer, J. H. (2010). Fundamentals of tree-ring research. University of Arizona Press, Tucson.

Suvorova, G. G., Yankova, L. S., Kopytova, L. D., \& Filippova, A. K. (2005) Optimal'nye faktory sredy i intensivnost' fotosinteza sosny obyknovennoj i listvennicy sibirskoj v Predbajkal'e [Optimal environmental factors and the intensity of photosynthesis of Scots pine and Siberian larch in Prebaikalia]. Siberian Journal of Ecology, 1, 85-95 (in Russian).

Torbenson, M. C. A. Stahle, D. W. Díaz J. V Cook, E. R \& Griffin, D. R. (2016). The relationship between earlywood and latewood ring-growth across North America. Tree Ring Research, 72(2), 53-66.
Vaganov, E. A., \& Kachaev, A. V. (1992). Dendroklimaticheskij analiz rosta sosny v lesobolotnyh fitocenozah Tomskoj oblasti [Dendroclimatic analysis of pine growth in forest phytocenoses of the Tomsk region]. Forestry, 6, 3-10 (in Russian).

Vaganov, E. A., Hughes, M. K., \& Shashkin, A. V. (2006). Growth dynamics of conifer tree rings: Images of past and future environments. Springer-Verlag, Berlin, Heidelberg.

Villanueva, D. J., Luckman, B. H., Stahle, D. W., Therrell, M. D., Cleaveland, M. K., Cerano-Paredes, J., Gutierrez-Garcia, G., Estrada-Avalos, J., \& Jasso-Ibarra, R. (2005). Hydroclimatic variability of the upper Nazas basin: Water management implications for the irrigated area of the Comarca Lagunera. Dendrocronologia, 22(3), 215-223.

Villanueva-Diaz, J., Stahle., D. W., Luckman, B. H., CeranoParedes, J., Therrell, M. D., Cleaveland, M. K., \& Cornejo Oviedo, E. (2007). Winter-spring precipitation reconstructions from tree rings for northeast Mexico. Climate Change, 83, 117-131.

Vitas, A. (2004). Dendroclimatological research of Scots pine (Pinus sylvestris L.) in the Baltic coastal zone of Lithuania. Baltic Forestry, 10(1), 65-71.

Zabuga, V. F., \& Zabuga, G. A. (2003). Zavisimost' radial'nogo prirosta sosny obyknovennoj ot faktorov vneshnej sredy v lesostepi Predbajkal'ya [The dependence of the radial growth of Scots pine on environmental factors in the Forest-Steppe Prebaikalia]. Forestry, 5, 30-37 (in Russian).

Zabuga, V. F., \& Zabuga, G. A. (2006). Vliyanie faktorov vneshnej sredy na ros stvola sosny obyknovennoj v lesostepnom Predbajkal'e [Influence of environmental factors on growth of the Archangel fir trunk in the Forest-Steppe Prebaikalia]. Conifers of the Boreal Area, 23(3), 86-95 (in Russian).

Zobel, B. J., \& Jett, J. B. (1995). Genetics of wood production. Springer Verlag, Berlin.

Zunde, M., Briede, A., \& Elferts, D. (2008). The influence of climatic factors on the radial growth of Scots pine (Pinus sylvestris) in Western Latvia. Proceeding of the Latvian Academy of Sciences, Natural, Exact, and Applied Sciences, 62(3), 120-128 